\title{
DIAGNOSIS PENYAKIT HIPERTENSI MENGGUNAKAN METODE CASE-BASED REASONING
}

\section{HYPERTENSION DIAGNOSIS USING CASE-BASED REASONING}

\author{
Amalia Beladinna Arifa ${ }^{1}$, Gita Fadila Fitriana ${ }^{2}$ \\ ${ }^{1}$ Fakultas Informatika, Program Studi Informatika \\ ${ }^{2}$ Fakultas Informatika, Program Studi Rekayasa Perangkat Lunak \\ 1,2Institut Teknologi Telkom Purwokerto \\ amalia@ittelkom-pwt.ac.id
}

\begin{abstract}
Abstrak
Hipertensi adalah kondisi ketika tekanan darah pada pembuluh darah bersih meningkat secara kronik. Jika tidak segera ditangani dapat menyebabkan peningkatan resiko kejadian penyakit lainnya, misalnya kardiovaskuler, serebrovaskuler dan renovaskuler. Diagnosis penyakit hipertensi perlu ditegakkan sedini mungkin guna menurunkan peningkatan resiko kejadian penyakit lainnya. Penelitian ini bertujuan menghasilkan sistem yang mengimplementasikan metode Case-Based Reasoning yang dapat membantu paramedis untuk mendiagnosis penyakit hipertensi. Implementasi sistem dirancang menggunakan bahasa pemrograman PHP serta penyimpanan data kasus menggunakan MySQL. Kasuskasus penyakit hipertensi yang sudah berhasil ditangani oleh dokter dijadikan sebagai data acuan untuk mendiagnosis kasus hipertensi yang baru. Kasus baru yang berisi faktor resiko, gejala dan riwayat penyakit selanjutnya dicari kemiripannya dengan kasus-kasus lama dengan cara menghitung nilai similaritas menggunakan Minkowski Distance. Pengujian dilakukan pada 172 data menggunakan 10-fold Cross-Validation. Hasil perhitungan dengan menetapkan threshold sebesar 0,90 didapatkan tingkat akurasi sebesar 94,71\%. Hasil penelitian menunjukkan implementasi Case-Based Reasoning dapat digunakan untuk melakukan diagnosis penyakit hipertensi.
\end{abstract}

Kata Kunci: Hipertensi, Case-Based Reasoning, Minkowski Distance, K-Fold Cross-Validation

\begin{abstract}
Hypertension is a condition when the blood pressure in the blood vessels increases chronically. If it is not treated immediately, it can increase the risk of other diseases, such as cardiovascular, cerebrovascular, and renovascular. Therefore, the detection of hypertension needs to be upheld early to reduce the increased risk of other conditions. This study aims to build a system that
\end{abstract}


implements the Case-Based Reasoning method that can help paramedics to diagnose hypertension. The implementation is designed using PHP and data storage cases using MySQL. Cases of hypertension that have been healed by a doctor can be used as a reference to deal with the diagnosis of new hypertension cases. Further claims that contain risk factors, symptoms and a history of the patient's disease are searched for similarities with old situations by calculating the similarity value using Minkowski Distance. Tests carried out on 172 data using 10-fold Cross-Validation. The outcome of the trial by setting the similarity threshold to 0.90 obtained an accuracy rate of $94.71 \%$. The results showed that Case-Based Reasoning could be used to diagnose hypertension.

Keywords: Hypertension, Case-Based Reasoning, Minkowski Distance, KFold Cross-Validation

\section{PENDAHULUAN}

Hipertensi adalah kondisi ketika tekanan darah pada pembuluh darah bersih meningkat secara kronik. Jika tidak segera ditangani, dalam jangka panjang akan menyebabkan peningkatan resiko kejadian penyakit lain seperti kardiovaskuler, serebrovaskuler dan renovaskuler. Prevalensi hipertensi di Indonesia berdasarkan hasil pengukuran tekanan darah pada usia di atas 18 tahun sebesar 25,8\%. Berdasarkan data tersebut, dari $25,8 \%$ penderita hipertensi hanya $1 / 3$ yang terdiagnosis dan $2 / 3$ sisanya tidak terdiagnosis [1]. Artinya, masih ada penderita hipertensi yang tidak terdiagnosis oleh tenaga kesehatan serta tidak menjalani pengobatan sesuai anjuran kesehatan. Hal tersebut menyebabkan hipertensi menjadi salah satu penyebab kematian tertinggi di Indonesia karena tidak mendapat penanganan yang tepat.
Mengintegrasikan teknologi komputer dan kecerdasan buatan ke dalam pelayanan kesehatan merupakan salah satu pendekatan untuk mengatasi kekurangan tenaga ahli (dokter), baik dari segi ketersediaan dan keahlian. Tenaga kesehatan yang memiliki keahlian dalam penanganan kesehatan seringkali tidak diimbangi dengan ketersediaannya ketika sedang dibutuhkan. Hal ini dapat beresiko kurang tepatnya penanganan yang diberikan kepada pasien yang membutuhkan pertolongan. Oleh karena itu perlu ditegakkan diagnosis penyakit hipertensi sedini mungkin untuk menurunkan peningkatan resiko kejadian penyakit lain.

Case-Based

Reasoning merupakan metode penalaran komputer yang memanfaatkan pengetahuan lama untuk menyelesaikan permasalahan baru. 
Pengetahuan lama berupa dokumentasi permasalahan yang telah memiliki solusi. Solusi tersebut dapat digunakan untuk menyelesaikan permasalahan baru yang serupa. Dalam kasus penyakit hipertensi, tenaga ahli yang berpengalaman yaitu dokter spesialis penyakit dalam, akan mendiagnosis seorang pasien yang mengidap penyakit hipertensi dengan memeriksa, mempertimbangkan keluhan yang dirasakan dan seringkali mengingat kembali pada pengalaman terdahulunya ketika berhasil menangani pasien lama yang menunjukkan pemeriksaan dan keluhan yang sama untuk mengambil kesimpulan awal. Kasus-kasus penyakit hipertensi yang berhasil ditangani oleh dokter dapat dijadikan acuan untuk mendiagnosis kasus penyakit hipertensi baru. Dengan implementasi Case-Based Reasoning diharapkan dapat membantu paramedis untuk mengambil keputusan dalam melakukan diagnosis penyakit hipertensi pada pasien baru.

Terdapat empat proses penting pada siklus Case-Based Reasoning, yaitu retrieve, reuse, revise dan retain. Untuk mencari kemiripan antara kasus lama dan kasus baru dihitung menggunakan ukuran jarak kedekatan (similaritas) yang terdapat pada proses retrieve. Perhitungan ukuran jarak kedekatan pada Case-Based Reasoning dapat diterapkan dengan berbagai macam metode, salah satunya adalah Minkowski Distance.

Case-Based Reasoning telah banyak diterapkan untuk menyelesaikan permasalahan di bidang medis, diantaranya pada kasus penyakit stroke dan penyakit jantung. Pada kasus penyakit stroke, untuk mencari kemiripan antar kasus menggunakan metode perhitungan Jaccard Coefficient dan Siriraj Score untuk membedakan tipe penyakit stroke iskemik dan hemoragik, serta menggunakan metode indexing dalam melakukan retrieve kasus. Berdasarkan pada data uji 45 kasus dan basis kasus 135 kasus, diperoleh hasil bahwa dengan menetapkan threshold similaritas 0,70 sistem Case-Based Reasoning dapat mendiagnosis penyakit stroke dengan sensitivitas $86,95 \%$ dan akurasi $(84,44 \%$ tanpa menggunakan metode indexing, $81,67 \%$ menggunakan metode indexing) [2]. Pada kasus penyakit jantung, sistem Case-Based Reasoning menerapkan metode perhitungan similaritas Minkowski Distance. Berdasarkan pada 134 data pada basis kasus, 58 data baru diujikan pada sistem dan memiliki tingkat akurasi sebesar 100\% dengan menetapkan nilai threshold sebesar 80 [3]. 
METODE PENELITIAN

\section{Deskripsi Model Case-Based Reasoning}

Case-Based Reasoning terdiri dari empat proses, yaitu retrieve, reuse, revise dan retain. Proses pada sistem dimulai dengan memasukkan sebuah kasus baru yang terdiri dari data faktor resiko, data keluhan yang dirasakan dan data riwayat penyakit. Setelah kasus baru dimasukkan, kemudian dilakukan pencocokan dengan kasuskasus lama di dalam basis kasus menggunakan rumus perhitungan ukuran jarak kedekatan (retrieve). Hasil dari perhitungan ukuran jarak kedekatan berupa nilai similaritas tertinggi yang dihasilkan antara kasus baru dengan kasus lama. Proses untuk menghitung nilai similaritas terbagi menjadi dua langkah, yaitu: 1) menghitung nilai similaritas lokal untuk fitur data bertipe numerik dan fitur data bertipe simbolik, dan 2) menghitung nilai similaritas global dengan mengalikan setiap kesamaan dari masing-masing fitur dengan nilai bobot menggunakan Minkowski Distance Similarity. Nilai similaritas bernilai antara 0 sampai dengan 1 . Sedangkan nilai bobot diperoleh dari hasil konsultasi dengan dokter/pakar.

Sistem Case-Based Reasoning mengeluarkan informasi sesuai dengan hasil perhitungan nilai similaritas. Nilai batas similaritas (threshold) yang diterapkan yaitu sebesar 0,90. Apabila nilai similaritas global lebih besar daripada nilai threshold dan bernilai 1 , informasi diagnosis penyakit hipertensi dari kasus lama dijadikan sebagai solusi bagi kasus baru (reuse). Apabila nilai similaritas global lebih besar daripada nilai threshold namun tidak bernilai 1 , informasi diagnosis penyakit hipertensi dari kasus lama dijadikan sebagai solusi bagi kasus baru dan rekomendasi terapi dari kasus lama akan diperbaiki terlebih dahulu oleh tenaga ahli atau pakar (revise). Rekomendasi terapi yang telah diperbaiki oleh ahli atau pakar kemudian ditampilkan kembali kepada paramedis sebagai solusi rekomendasi terapi bagi kasus baru. Sebaliknya, apabila nilai similaritas global lebih kecil daripada nilai threshold, sistem tidak akan memberikan informasi diagnosis penyakit hipertensi dan rekomendasi terapi, yang artinya kasus baru tidak cukup kuat untuk didiagnosis sebagai penyakit hipertensi. Proses yang terjadi dalam sistem ditunjukkan pada Gambar 1. 


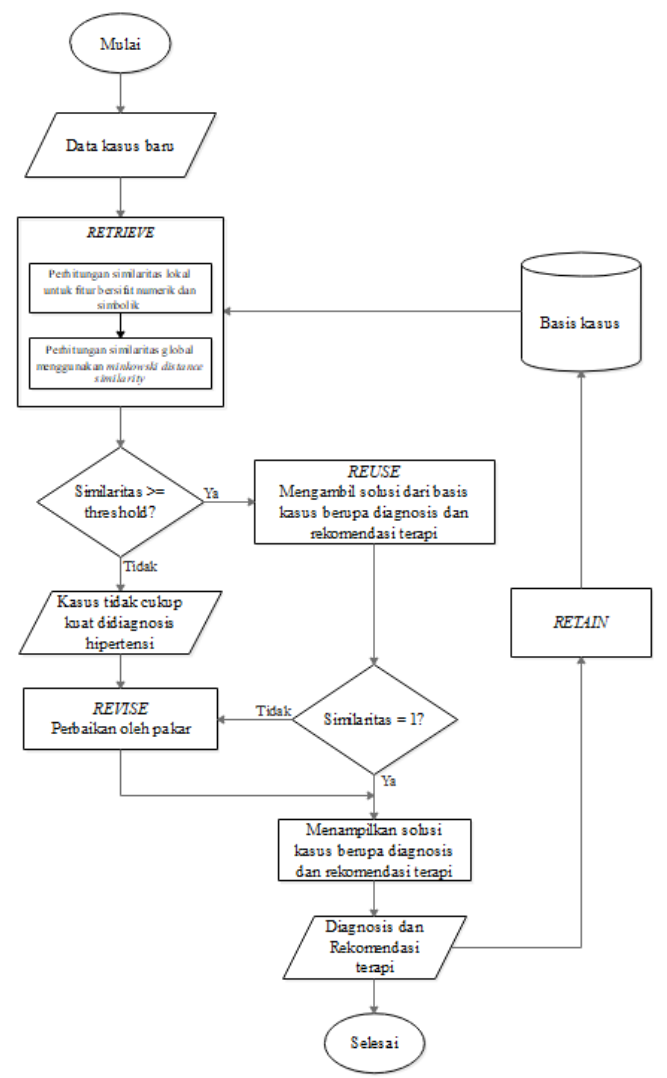

Gambar 1. Model Case-Based Reasoning

Kasus baru yang telah memiliki solusi berupa diagnosis penyakit hipertensi dan rekomendasi terapi, selanjutnya disimpan ke dalam sistem sebagai pengetahuan baru bagi sistem (retain). Penyimpanan kasus baru hanya dilakukan oleh dokter/pakar.

\section{Representasi Kasus}

Kumpulan kasus penyakit hipertensi yang telah memiliki solusi direpresentasikan ke dalam suatu bentuk tertentu untuk dijadikan sebagai pengetahuan bagi sistem. Pilihan bentuk representasi kasus bergantung pada domain permasalahan dan struktur data kasus. Dalam domain kesehatan, umumnya representasi kasus terbagi atas dua bagian, yaitu kondisi pasien (permasalahan) dan diagnosis penyakit serta pengobatan (solusi). Setelah kasus-kasus penyakit hipertensi direpresentasikan kemudian akan disimpan ke dalam sebuah storage.

Model representasi yang digunakan adalah model flat frame, yang memungkinkan untuk data bertipe numerik dan simbolik (kategori) [4]. Permasalahan sebuah kasus direpresentasikan melalui tiga kelompok fitur yaitu faktor resiko, keluhan yang dirasakan dan riwayat penyakit. Sedangkan solusi sebuah kasus direpresentasikan melalui dua fitur yaitu diagnosis penyakit hipertensi dan rekomendasi terapi. Nama dan cara penilaian fitur ditunjukkan pada Tabel 1.

Tabel 1. Nama Fitur dan Penilaian

\begin{tabular}{ll}
\hline \multicolumn{1}{c}{ Nama Fitur } & \multicolumn{1}{c}{ Nilai Fitur } \\
\hline Faktor Resiko & \\
Usia & Numerik \\
Jenis kelamin & L=1 dan $\mathrm{P}=0$ \\
Tekanan darah sistolik & Numerik \\
Tekanan darah diastolik & Numerik \\
Jumlah nadi & Numerik \\
Jumlah napas & Numerik \\
\hline Gejala & \\
G01 - Jantung berdebar & Ya=1,Tidak=0 \\
G02 - Mual & Ya=1,Tidak=0 \\
G03 - Pusing & Ya=1,Tidak=0 \\
G04 - Lemas & Ya=1,Tidak=0 \\
G05 - Sakit kepala & Ya=1,Tidak=0 \\
G06 - Nyeri dada & Ya=1,Tidak=0 \\
G07 - Sesak napas & Ya=1,Tidak=0 \\
G08 - Mimisan & Ya=1,Tidak=0 \\
\hline
\end{tabular}




\begin{tabular}{|c|c|}
\hline $\begin{array}{l}\text { G09 - Pandangan kabur } \\
\text { G10 - Hilang Kesadaran }\end{array}$ & $\begin{array}{l}\text { Ya }=1, \text { Tidak }=0 \\
\mathrm{Ya}=1, \text { Tidak }=0\end{array}$ \\
\hline \multicolumn{2}{|l|}{ Riwayat penyakit } \\
\hline R01 - Hipertensi & $\mathrm{Ya}=1$, Tidak $=0$ \\
\hline R02 - Diabetes mellitus & $\mathrm{Ya}=1$, Tidak $=0$ \\
\hline R03 - Stroke & $\mathrm{Ya}=1$, Tidak $=0$ \\
\hline R04 - Jantung & $\mathrm{Ya}=1$, Tidak $=0$ \\
\hline R05 - Ginjal & $\mathrm{Ya}=1$, Tidak $=0$ \\
\hline \multicolumn{2}{|l|}{ Diagnosis Penyakit } \\
\hline P01 & Pre-Hipertensi \\
\hline P02 & $\begin{array}{l}\text { Hipertensi Tingkat- } \\
1\end{array}$ \\
\hline P03 & $\begin{array}{l}\text { Hipertensi Tingkat- } \\
2\end{array}$ \\
\hline P04 & Hipertensi Urgensi \\
\hline P05 & $\begin{array}{l}\text { Hipertensi } \\
\text { Emergensi }\end{array}$ \\
\hline \multicolumn{2}{|l|}{ P06 } \\
\hline \multirow[t]{2}{*}{ Rekomendasi terapi } & $\begin{array}{l}\text { Kontrol penurunan } \\
\text { tekanan darah } \\
\text { dengan mengubah } \\
\text { gaya hidup }\end{array}$ \\
\hline & $\begin{array}{l}\text { Pemberian lini } \\
\text { pertama obat } \\
\text { antihipertensi }\end{array}$ \\
\hline
\end{tabular}

\section{Proses Retrieve dan Reuse}

Proses retrieve pada sistem melalui perhitungan similaritas antar kasus. Perhitungan similaritas dilakukan dengan mengukur kemiripan setiap fitur pada kasus baru dengan setiap fitur kasus lama, menggunakan ukuran jarak kedekatan. Proses perbandingan kasus lama dilakukan per satu kasus. Setiap fitur kasus memiliki bobot yang berbeda untuk setiap jenis penyakit hipertensi. Semua nilai similaritas yang dihasilkan oleh setiap kasus lama kemudian dicatat dan diambil satu nilai tertinggi. Kasus lama dengan nilai similaritas tertinggi tersebut merupakan kasus yang paling mirip dengan kasus baru. Proses reuse adalah menampilkan kasus lama yang memiliki nilai similaritas tertinggi yang dihasilkan pada proses retrieve, kemudian solusi dari kasus lama tersebut dijadikan sebagai solusi bagi kasus baru.

Proses perhitungan similaritas antar kasus terdiri dari perhitungan similaritas lokal antar fitur kasus dan perhitungan similaritas global antar kasus.

\section{Similaritas Lokal}

Perhitungan similaritas lokal berada pada level setiap kemunculan fitur pada kasus baru. Similaritas lokal yang digunakan terdiri dari dua, yaitu untuk fitur bertipe numerik dan simbolik. Data kasus yang merupakan fitur bertipe numerik adalah usia, tekanan darah sistolik, tekanan darah diastolik, jumlah nadi dan jumlah napas. Data kasus selain itu yaitu jenis kelamin, gejala dan riwayat penyakit merupakan fitur bertipe simbolik. Untuk menghitung fitur bertipe data numerik ditunjukkan pada persamaan (1) dan fitur bertipe data simbolik ditunjukkan pada persamaan (2) [5]:

a. Tipe Data Numerik

$f\left(S_{i}, T_{i}\right)=1-\frac{\left|S_{i}-T_{i}\right|}{f_{\max }-f_{\min }}$ 
dengan $S_{i}$ adalah nilai fitur ke- $i$ dari kasus lama dan $T_{i}$ adalah nilai fitur ke- $i$ dari kasus baru, sedangkan $f_{\max }$ adalah nilai tertinggi fitur ke- $i$ yang digunakan dan $f_{\min }$ adalah nilai terendah fitur ke- $i$ yang digunakan.

b. Tipe Data Simbolik

$f\left(S_{i}, T_{i}\right)=\left\{\begin{array}{l}0, \text { jika } S_{i} \neq T_{i} \\ 1, \text { jika } S_{i}=T_{i}\end{array}\right.$

\section{Similaritas Global}

Perhitungan similaritas global berada pada level objek atau kasus. Similaritas global digunakan untuk menghitung kemiripan antara kasus baru dengan kasus-kasus lama yang tersimpan pada basis kasus. Metode perhitungan similaritas global yang digunakan adalah Minkowski Distance Similarity, seperti yang ditunjukkan pada persamaan (3) sebagai berikut [6]:

$\operatorname{Sim}\left(S_{i}, T_{i}\right)=\left(\frac{\sum_{i=1}^{n} w_{i}{ }^{r} \times\left|f\left(S_{i}, T_{i}\right)\right|^{r}}{\sum_{i=1}^{n} w_{i}{ }^{2}}\right)^{1 / r}$

dengan $\operatorname{Sim}\left(S_{i}, T_{i}\right)$ merupakan nilai similaritas antara kasus lama $\left(S_{i}\right)$ dan kasus baru $\left(T_{i}\right), f\left(S_{i}, T_{i}\right)$ merupakan kemiripan fitur ke- $i$ antara kasus lama dan kasus baru yang dihasilkan dari similaritas lokal, $n$ merupakan jumlah fitur pada masing-masing kasus, $i$ merupakan fitur individu yang berada diantara $1 \mathrm{~s} / \mathrm{d} n, w_{i}$ merupakan bobot fitur ke- $i$ dan $r$ merupakan faktor Minkowski. Nilai bobot untuk setiap fitur ditentukan oleh dokter/pakar, dalam penelitian ini adalah dokter spesialis penyakit dalam. Pembobotan fitur perlu dilakukan karena terdapat perbedaan kepentingan antara satu fitur dengan fitur lainnya.

Nilai $r$ adalah bilangan positif $\geq$ 1. Jika $r=1$ dikenal sebagai Manhattan/City block distance, jika $r=2$ dikenal sebagai Euclidean distance dan jika $r=$ tak terhingga dikenal sebagai Chebyshev distance [7]. Pada penelitian ini menggunakan $r=3$ yang dikenal dengan Minkowski Distance.

\section{Desain Arsitektur Sistem}

Arsitektur sistem dirancang berdasarkan hasil analisis kebutuhan sistem. Sistem dirancang untuk dapat memberikan diagnosis dan rekomendasi terapi hipertensi berdasarkan data yang dimasukkan oleh pengguna. Pengguna sistem terdiri dari tiga yaitu administrator sebagai pengguna yang memasukkan data-data basis kasus ke dalam sistem (user manager), paramedis sebagai pengguna yang memasukkan data baru untuk dicari solusinya (novice user) dan dokter/pakar sebagai pengguna yang melakukan perbaikan pada solusi kasus baru serta memvalidasi solusi kasus baru untuk dimasukkan ke dalam basis kasus (expert). Arsitektur sistem yang dibangun ditunjukkan pada Gambar 2. 


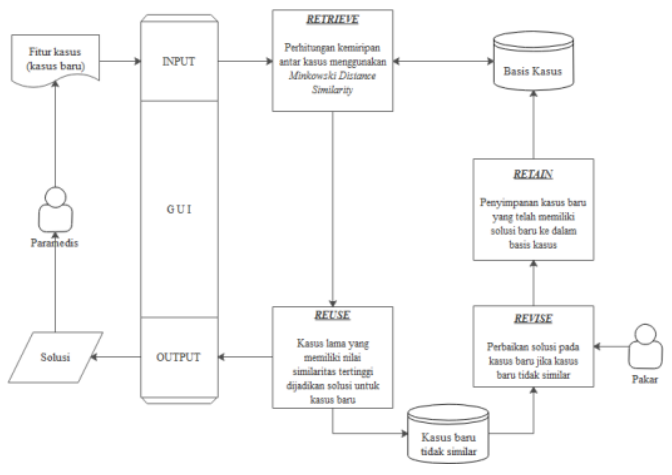

Gambar 2. Arsitektur Sistem CaseBased Reasoning

\section{Rancangan Pengujian}

Pengujian dilakukan menggunakan $K$-fold Cross-Validation. Dalam permasalahan klasifikasi, $K$-fold CrossValidation merupakan metode terbaik untuk digunakan dalam memvalidasi dan memilih sebuah classifier [8]. Pendekatan $K$-fold Cross-Validation yaitu sebagian data digunakan sebagai data latih dan sebagian data yang lain sebagai data uji. Prosedur akan diulang sebanyak K-kali sehingga setiap data pada setiap fold akan tepat satu kali digunakan sebagai data uji.

Untuk dapat mengetahui ketepatan suatu klasifikasi, dilakukan evaluasi dengan menghitung jumlah kelas positif yang diklasifikasikan dengan benar (true positives), jumlah kelas negatif yang diklasifikasikan dengan benar (true negatives), kelas negatif yang diklasifikasikan sebagai kelas positif (false positives) dan kelas positif yang diklasifikasikan sebagai kelas negatif (false negatives). Nilai TP, TN, FP dan FN digunakan untuk membentuk suatu confusion matrix kemudian dapat dihitung tingkat akurasi. Ilustrasi mengenai confusion matrix menggunakan dua kelas, yaitu TRUE dan FALSE ditunjukkan pada Tabel 2.

Tabel 2. Confusion Matrix

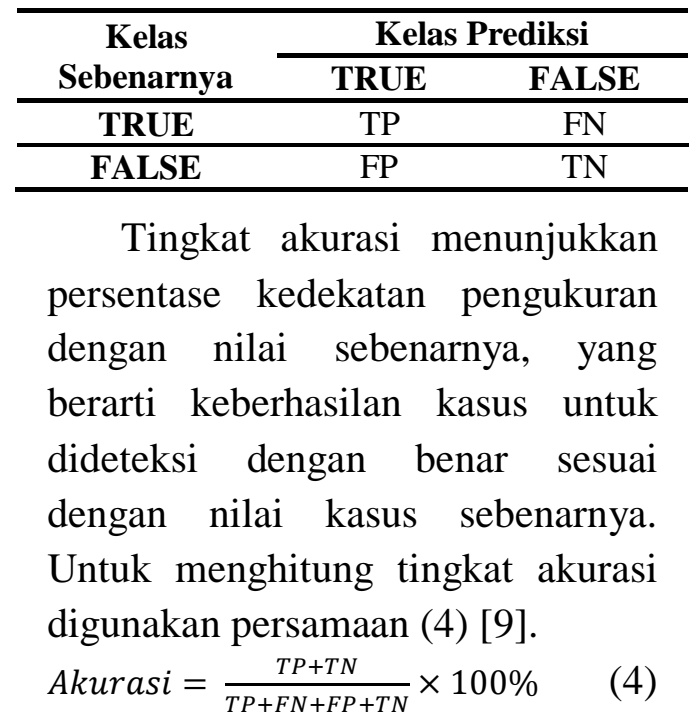

\section{HASIL DAN PEMBAHASAN}

Pencarian Nilai Similaritas Antar Kasus

Setiap data yang akan diujikan, terlebih dahulu melalui proses pencarian kemiripan antar kasus dengan menghitung similaritas. Nilai similaritas antar kasus didasarkan pada kemiripan pada hasil diagnosis antar kasus. Representasi antara kasus baru dan kasus lama yang akan dihitung nilai similaritasnya ditunjukkan pada Tabel 3.

Tabel 3. Representasi Antara Kasus Lama dan Kasus Baru

\begin{tabular}{ccc}
\hline \multirow{2}{*}{ Data } & Kasus Lama & Kasus \\
& $(\mathrm{S})$ & Baru \\
\hline
\end{tabular}




\begin{tabular}{lccc}
\hline & Nilai & Bobot & (T) \\
\hline Usia & 58 & 5 & 67 \\
\hline JK & 2 & 7 & 2 \\
\hline TDS & 211 & 10 & 210 \\
\hline TDD & 122 & 10 & 120 \\
\hline Nadi & 101 & 6 & 80 \\
\hline Napas & 28 & 5 & 20 \\
\hline G01 & 1 & 6 & 1 \\
\hline G02 & 1 & 5 & 0 \\
\hline G03 & 1 & 7 & 0 \\
\hline G04 & 0 & 6 & 0 \\
\hline G05 & 0 & 7 & 0 \\
\hline G06 & 1 & 5 & 1 \\
\hline G07 & 1 & 5 & 1 \\
\hline G08 & 0 & 7 & 0 \\
\hline G09 & 0 & 6 & 0 \\
\hline G10 & 0 & 7 & 0 \\
\hline R01 & 1 & 9 & 1 \\
\hline R02 & 0 & 8 & 0 \\
\hline R03 & 0 & 9 & 0 \\
\hline R04 & 1 & 9 & 1 \\
\hline R05 & 0 & 9 & 0 \\
\hline Diagnosis & $\begin{array}{l}\text { Hipertensi } \\
\text { emergensi }\end{array}$ & $?$ \\
\hline & $\begin{array}{l}\text { Kontrol } \\
\text { penurunan }\end{array}$ \\
tekanan darah \\
dengan \\
mengubah gaya \\
Terapi
\end{tabular}

Tahapan dalam mencari diagnosis hipertensi menggunakan perhitungan similaritas Minkowski Distance adalah sebagai berikut:
A. Similaritas Lokal
1. Fitur Faktor Resiko

a) Fitur Usia

$$
f\left(S_{1}, T_{1}\right)=1-\frac{|67-58|}{87-31}=0,842
$$

b) Fitur Jenis Kelamin $f\left(S_{2}, T_{2}\right)=1$

c) Fitur Nilai TDS

$$
\begin{array}{r}
f\left(S_{3}, T_{3}\right)=1-\frac{|211-210|}{240-120} \\
=0,992
\end{array}
$$

d) Fitur Nilai TDD

$$
\begin{array}{r}
f\left(S_{4}, T_{4}\right)=1-\frac{|122-120|}{130-80} \\
=0,96
\end{array}
$$

e) Fitur Jumlah Nadi

$$
\begin{array}{r}
f\left(S_{5}, T_{5}\right)=1-\frac{|101-80|}{125-60} \\
=0,677
\end{array}
$$

f) Fitur Jumlah Napas

$$
f\left(S_{6}, T_{6}\right)=1-\frac{|28-20|}{28-12}=0,5
$$

2. Fitur Gejala
a) Gejala Jantung Berdebar $f\left(S_{7}, T_{7}\right)=1$
b) Gejala Nyeri Dada $f\left(S_{12}, T_{12}\right)=1$
c) Gejala Sesak Napas $f\left(S_{13}, T_{13}\right)=1$

3. Fitur Riwayat Penyakit
a) Riwayat Penyakit Hipertensi $f\left(S_{14}, T_{14}\right)=1$
b) Riwayat Penyakit Jantung $f\left(S_{17}, T_{17}\right)=1$

B. Similaritas Global menggunakan Minkowski Distance

$$
\operatorname{Sim}(S, T)=\left(\frac{4064,818}{4984}\right)^{1 / 3}=0,934
$$

Berdasarkan hasil perhitungan similaritas antara kasus baru dengan kasus lama didapatkan bahwa nilai similaritas adalah 0,934. Nilai similaritas memiliki nilai di atas threshold yang ditetapkan, yaitu 0,90. Solusi kasus lama berupa diagnosis penyakit Hipertensi Emergensi dan rekomendasi terapi dijadikan sebagai solusi bagi kasus baru. Namun, solusi rekomendasi 
terapi kasus lama akan melalui proses perbaikan oleh dokter/pakar terlebih dahul karena rekomendasi terapi didasarkan pada faktor resiko dan riwayat penyakit dari pengguna.

\section{Proses Diagnosis Penyakit Hipertensi}

Case-Based Reasoning untuk diagnosis penyakit hipertensi merupakan sistem yang berbasis website dan diimplementasikan menggunakan bahasa pemrograman PHP serta penyimpanan data basis kasus menggunakan MySQL. Sistem yang dibangun bertujuan untuk dapat melakukan diagnosis penyakit hipertensi berdasarkan kasus baru yang dimasukkan oleh pengguna, yaitu paramedis. Paramedis memasukkan fitur-fitur kasus baru yang terdiri dari usia, jenis kelamin, nilai TDS, nilai TDD, nilai jumlah nadi, nilai jumlah napas, gejala dan riwayat penyakit ke dalam form diagnosis hipertensi. Sebuah kasus baru, yang tidak terdapat pada basis kasus, diujicobakan ke dalam sistem Case-Based Reasoning untuk diagnosis penyakit hipertensi. Kemudian sistem akan mencari kasuskasus lama pada basis kasus yang memiliki kemiripan dengan kasus baru dengan cara menghitung nilai similaritas. Setelah ditemukan kasus lama yang memiliki nilai similaritas tertinggi dengan kasus baru, maka solusi dari kasus lama dijadikan sebagai solusi bagi kasus baru. Kasus lama yang terpilih tersebut akan disampaikan kepada paramedis sebagai keluaran dari sistem. Berdasarkan hasil pengujian kasus baru terhadap semua kasus pada sistem, similaritas tertinggi dihasilkan oleh kasus K063 dengan nilai similaritas 0,9277086 seperti diperlihatkan pada Gambar 3.

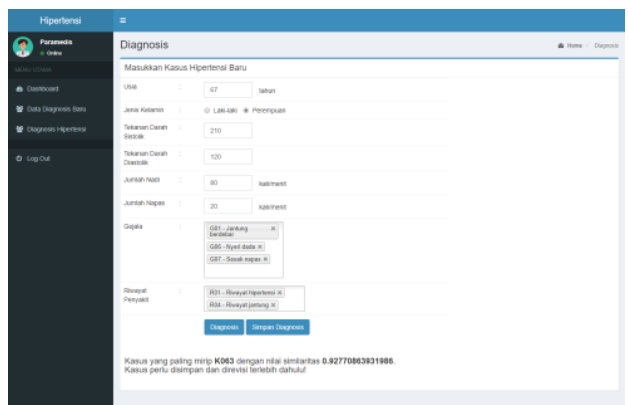

Gambar 3. Kasus Baru yang

Diujicobakan pada Sistem

Nilai similaritas tertinggi yang dihasilkan antara kasus lama dan kasus baru tersebut berada di atas nilai threshold $(0,90)$, maka solusi kasus lama berupa diagnosis akan dijadikan solusi bagi kasus baru. Karena nilai similaritas yang dihasilkan tidak mencapai nilai 1 , solusi berupa rekomendasi terapi harus dilakukan perbaikan terlebih dahulu oleh dokter/pakar. Kemudian paramedis menyimpan kasus baru tersebut sebagai kasus sementara yang perlu diperbaiki oleh dokter/pakar seperti pada Gambar 4. 


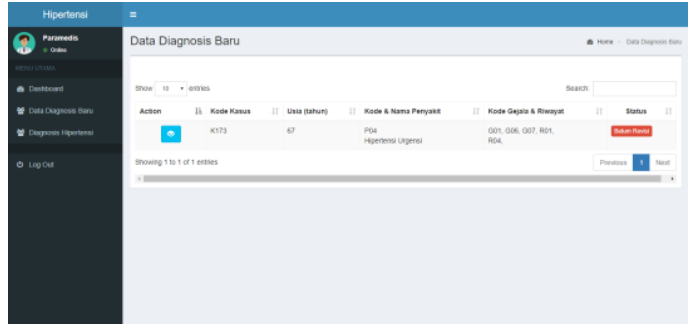

Gambar 4. Kasus Baru yang Perlu Diperbaiki Dokter/Pakar

Setelah dokter/pakar selesai melakukan perbaikan, paramedis menerima notifikasi berupa kasus baru telah selesai melalui proses revisi. Kemudian paramedis menggunakan solusi kasus lama termirip dengan kasus baru seperti terlihat pada Gambar 5. Setelah itu kasus baru disimpan ke dalam basis kasus sebagai pengetahuan baru. Proses penyimpanan kasus baru ini dilakukan oleh dokter/pakar.

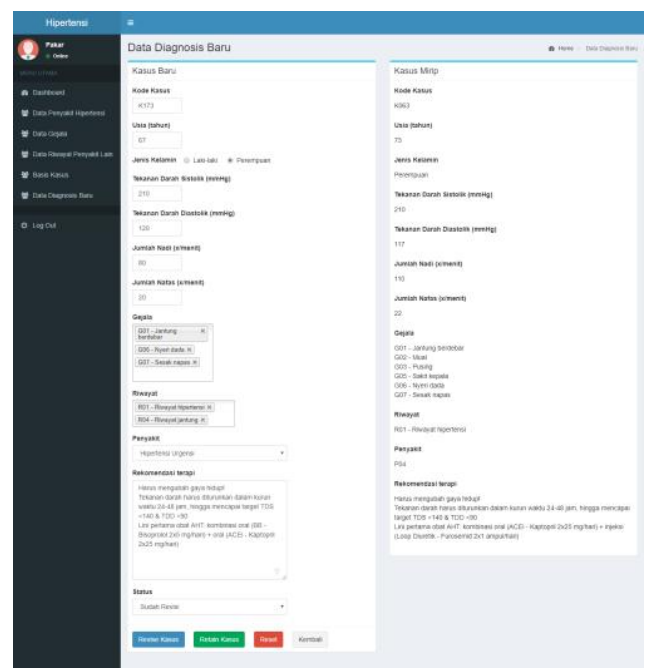

Gambar 5. Hasil Diagnosis

\section{Hasil Pengujian}

Data yang digunakan sebagai basis kasus dalam pengujian akurasi sistem sebanyak 172 kasus. Sebuah kasus terdiri dari data faktor resiko, data gejala, data riwayat penyakit, data diagnosis dan data rekomendasi terapi. Data diagnosis yang terdiri dari lima kelas penyakit hipertensi dijadikan sebagai pengukuran akurasi. Distribusi basis kasus sesuai kelas diagnosis penyakit hipertensi disajikan pada Tabel 4.

\begin{tabular}{lc}
\multicolumn{2}{c}{ Tabel 4. Distribusi Basis Kasus } \\
\hline Kelas Penyakit Hipertensi & $\begin{array}{c}\text { Jumlah } \\
\text { Data }\end{array}$ \\
\hline Normal & 10 \\
\hline Pre-Hipertensi & 14 \\
\hline Hipertensi Tingkat-1 & 34 \\
\hline Hipertensi Tingkat-2 & 38 \\
\hline Hipertensi Urgensi & 54 \\
\hline Hipertensi Emergensi & 22 \\
\hline \multicolumn{1}{c}{ Jumlah } & 172 \\
\hline
\end{tabular}

Pengujian akurasi dilakukan dengan menerapkan $\mathrm{K}$-Fold Cross Validation menggunakan $\mathrm{K}=10$ pada data basis kasus sebanyak 172 data. Data basis kasus dibagi ke dalam jumlah yang sama rata pada setiap fold. Pengujian dilakukan sebanyak 10 kali dan di setiap pengujian, satu fold menjadi data uji dan sisa fold lainnya menjadi data latih. Untuk setiap kali pengujian dihitung tingkat akurasinya. Tingkat akurasi secara keseluruhan didapatkan dari rata-rata seluruh pengujian.

Tabel 5. Hasil Pengujian K=10

\begin{tabular}{cc}
\hline Pengujian ke- & Akurasi (\%) \\
\hline 1 & 100 \\
\hline 2 & 100 \\
\hline 3 & 100 \\
\hline 4 & 88,24 \\
\hline 5 & 88,24 \\
\hline
\end{tabular}




\begin{tabular}{cc}
\hline 6 & 100 \\
\hline 7 & 94,12 \\
\hline 8 & 94,12 \\
\hline 9 & 94,12 \\
\hline 10 & 88,24 \\
\hline Rata-rata Akurasi & $\mathbf{9 4 , 7 1}$ \\
\hline
\end{tabular}

Tabel 5 menunjukkan rekapitulasi hasil rata-rata pengujian menggunakan 10-fold Cross Validation. Tingkat akurasi sistem sebesar 94,71 \% didapatkan dengan mengimplementasikan metode CaseBased Reasoning dan menggunakan perhitungan similaritas Minkowski Distance dengan threshold 0,90.

\section{KESIMPULAN}

Berdasarkan penelitian yang telah dilakukan, dapat disimpulkan bahwa Case-Based Reasoning dapat diimplementasikan dalam bidang medis untuk melakukan diagnosis penyakit hipertensi. Sistem CaseBased Reasoning yang dibangun dengan menggunakan metode perhitungan similaritas Minkowski Distance selalu memberikan keluaran berupa kasus lama yang memiliki nilai similaritas tertinggi sebagai solusi bagi kasus baru. Hasil pengujian terhadap 172 data kasus menggunakan 10-fold Cross Validation memiliki tingkat akurasi sebesar $94,71 \%$.

\section{DAFTAR PUSTAKA}

[1]Balitbang Kemenkes RI. 2018. RISKESDAS (Laporan Nasional Riset Kesehatan Dasar 2018) [Online] Available at: http://labdata.litbang.kemkes.g o.id/ccount/click.php?id=19 [2]Rumui, N., Harjoko, A., dan Musdholifah A., 2018. CaseBased Reasoning for Stroke Disease Diagnosis. Indonesian Journal of Computing and Cybernetics Systems (IJCCS), Volume 12 Nomor 1 Januari 2018, Pp.33-42, ISSN: 24607258 (Online).

[3]Wahyudi, E. dan Pradasari, N., 2018. Case-Based Reasoning untuk Diagnosis Penyakit Jantung Menggunakan Metode Minkowski Distance. INTECOMS: Journal of Information Technology and Computer Science, Volume 1 Nomor 1 Juni 2018, Pp.119123, ISSN: 2614-1574 (Online).

[4]Pla, A., López, B., Gay, P., dan Pous, C., 2013. EXiT*CBR.v2: Distributed Case-Based Reasoning Tool for Medical Prognosis. Decision Support Systems, Volume 54 Nomor 3 Februari 2013, Pp.1499-1510. [5]Kang, Y. B., Krishnaswamy, S., dan Zaslavsky, A., 2014. A Retrieval Strategy for CaseBased Reasoning Using Similarity and Association Knowledge. IEEE Transactions on Cybernetics, Volume 44 Nomor 4 April 2014, Pp.473-487. 
[6]Núñez, H., Sànchez-Marrè, M., Cortés, U., Comas, J., Martínez, M., Rodríguez-Roda, I., dan Poch, M., 2004. A Comparative Study on The Use of Similarity Measures in Case-Based Reasoning to Improve the Classification of Environmental System Situations. Environmental Modelling \& Software, 19 (9), pp.809-819.

[7]De Soto, B. G. dan Adey, B. T., 2015. Investigation of the Casebased Reasoning Retrieval Process to Estimate Resources in Construction Projects. Procedia Engineering, Volume 123 2015, Pp.169-181.

[8]Christopher, J. J., Nehemiah H. K., and Kannan, A., 2015. A Clinical Decision Support System for Diagnosis of Allergic Rhinitis Based on Intradermal Skin Tests. Computers in Biology and Medicine, Volume 65 Oktober 2015, Pp.76-84.

[9]Sokolova, M. dan Lapalme, G, 2009. A Systematic Analysis of Performance Measures for Classification Tasks. Information Processing \& Management, Volume 44 Nomor 4 Juli 2009, Pp.427-437. 